\title{
EMLÉKEZÉS EGY NAGY HATÁSÚ TANÁREGYÉNISÉGRE, DR. CSORBA ZOLTÁNRA
}

\author{
KovÁts DÁNIEL \\ ny. föiskolai tanár \\ kovats.daniel@vnet.hu
}

Hetvenöt évvel ezelött ültem be először az iskolapadba, elmondhatom hát, hogy „történelmi” változásokat éltem meg az oktatás, a pedagógia kapcsán. S hadd tegyem rögtön hozzá: az az iskolapad szülőfalumban a csehszlovák állam által emelt kétszintes kockaépület egyik tantermében állt, ahol szlovákul szólt hozzám első tanító nénim. A vegyes nemzetiségü község magyar lakosai közé tartozván ragadt ugyan rám hatéves koromig néhány szlovák szó, tanulásom mégis nehézségekkel járt. A tanítónő, akinek nevére, sajnos, nem emlékszem, valamely távoli vidékről került hozzánk, nem értette nyelvemet. Olykor németül magyarázott meg nekem valamit, mert abban a szlováknál valamennyivel járatosabb voltam szepesi rokonságunk révén. A harmadik osztályba jártam, amikor novemberben a határszéli község Kassával együtt visszakerült Magyarországhoz, s - Drozda igazgató urat nem számítva - kicserélődött a tantestület. Sárkány tanító úr és a furcsa nevü, regényíróként is próbálkozó Mousonné Gaiotto Orsolya tanítónő irányítása mellett próbáltam pótolni alapismereteim hiányait. Amikor édesapám Miskolcon kapott állást, szüleim elköltözésünk előtt különórákra járattak a református paphoz, Kovács Lajos nagytiszteletủ úrhoz, hogy megkönnyítsék felzárkózásomat. A negyedik osztály vége felé kerültem át a miskolci Palóczi utcai református elemibe, ahol megtapasztalhattam társaimhoz képest érzékelhető lemaradásomat, ezért Molnár tanító úr külön is foglalkozott velem.

Nem voltam buta gyerek, szerettem olvasni, de alapismereti hiányosságaimat megszenvedtem középiskolai éveim alatt is. 1940 szeptemberében kerültem a köszegi Hunyadi Mátyás katonai nevelőintézetbe, s bizony az osztály gyengébbik feléhez tartoztam. Nem tanáraim miatt, ők reálisan ítélték meg teljesítményemet. Ott leginkább Zerinváry Szilárd hatott rám, aki a történelmet nagyon eredeti módon tanította: bizonyos témakörökböl beszámolóra kellett jelentkezni, s sikeres szereplés esetén - kivont kardját vállunkhoz érintve - lovaggá avatott bennünket. Később, a háború után Budapesten csillagászként szerzett elismerést. Géresi tanár úr az éneket tanította nekünk, tagja voltam énekkarának, szerepeltünk a rádióban is, igen sok népdal ismeretét köszönhetem neki. Katonai pályafutásomnak azonban véget vetett a front ideérkezése, a gimnázium felső négy osztályát már a miskolci református Lévay József Gimnáziumban végeztem el. Ez a nagy múltú, 1560-ban alapított is- 
kola örizte még a magyar kálvinista hagyományt az érettségink évében, 1948-ban bekövetkezett államosításig, s néhány kiváló tanáregyénisége erősen hatott reám. Közülük most $d r$. Csorba Zoltánt emelem ki, aki magyarra és angolra tanított, s két évig osztályfönököm volt.

A felelösen gondolkodó értelmiségi, a tudós tanár, a példát adó nevelő személyiségjegyei jutnak eszébe annak, aki ismerte $d r$. Csorba Zoltánt, s megkísérli fölidézni alakját. Ami belőle múlandó volt, már 35 éve nyugszik a miskolci Deszka-temetőben, hatása azonban él az immár megöszült egykori tanítványokban, s ma is vonzanak olvasókat becses müvelődéstörténeti írásai. Azok közé a pedagógus egyéniségek közé tartozott, akik karaktert adnak egy-egy iskolának, akiknek hatása alól nem tudja kivonni magát a diák. Alapos felkészültség, széles látókör, szellemi nyitottság, a nemzeti és humánus eszmények iránti elkötelezettség jellemezte. Daliás termete, érdeklődő tekintete, a szája sarkában meghúzódó mosolya jelezte életszeretetét; ugyanakkor valamiféle biztonságérzetet, fölényt is sugallt a tartása, annak az embernek a szilárdságát, aki különbséget tud tenni a tetszetős lim-lom és a valódi érték, a múló divat és a maradandó teljesítmény között.

Csorba Zoltán 1905. január 16-án született Miskolcon, édesapja vasúti tisztviselő volt, aki igyekezett elősegíteni tehetségesnek ítélt fia iskolázását. A református főgimnáziumba íratta be, ahol az ifjút tanulmányi eredményei kiemelték társai közül, sorra nyerte az irodalmi pályázatokat, s titkára lett a Kazinczy Ferenc Önképzökörnek. 1922-ben jeles eredménnyel tett érettségi vizsgát. A Trianont követő évek anyagi-társadalmi problémái nem kedveztek az értelmiségi pályára készülőknek. Ifjú vallástanárának, későbbi tanártársának, Balázs Gyözőnek a hatására és ajánlásával Csorba Zoltán a budapesti református teológiára jelentkezett, s ott is kitünt kiváló képességeivel. Ennek köszönhette, hogy másodéves korában már vallástanári feladattal bízták meg, s hogy az amerikai magyar reformátusok 1924-ben meghívták az Egyesült Államokba. Lelkészi szolgálata mellett tanulmányai folytatására is felhasználta otttartózkodását; 1926-ban baccalaureatusi fokozatot szerzett, a pittsburghi teológiai szemináriumban pedig megkapta a „master of sacred theology” címet. Disszertációjában a fiatalok vallási életének lélektani szempontú vizsgálatával foglalkozott. Hazatérve 1927-ben itthon is befejezte tanulmányait, s egy év múlva már egykori iskolájának tanára volt, s ezután is mindvégig kitartott szülővárosa mellett.

Iskolájának azonban nem hittanárként volt rá szüksége, ezért elősegítették bölcsészettudományi tanulmányait. Yolland Artúr professzor tanítványaként végezte el az angol tanári szakot a budapesti Pázmány Péter Tudományegyetemen, s 1943 januárjában ott bölcsészdoktorrá avatták. Közben, 1930-ban könyv alakban adta ki „Adalékok az amerikai magyar irodalom történetéhez” címü értekezését, 1942-ben pedig „,Miskolc és Borsod az irodalomban” címü kötetét. Szakirodalmi munkássága megalapozta tudósi tekintélyét, a gimnáziumi tanítás mellett rendszeresen szere- 
pelt a miskolci szabadegyetemen, 1939 és 1944 között a kassai rádióban, angolt tanított a jogakadémián, feltárta iskolája nagy értékủ könyvtárának kincseit.

A kultúrtörténeti hagyomány mellett a kor szellemi kihívásai is érdekelték. Karácsony Sándor, Györffy István és a népi írók szellemisége érintette meg; bekapcsolódott az úgynevezett falumunka kezdeményezéseibe, a tehetségkutatásba, a magyar falu hagyománykincsének feltárásába. Tanártársaival falukiszállásokat szervezett, egyháza támogatásával segítette elő a szegény sorsú parasztfiatalok középiskolai továbbtanulását. Abban az osztályban, amely 1940-ben kezdte gimnáziumi tanulmányait, amelynek Csorba Zoltán az osztályfönöke volt, s amelynek ötödiktől magam is diákja lettem, hat olyan kiváló tehetségü fiú kapott lehetőséget a kiemelkedésre, akik e segítség nélkül anyagi okok miatt nem juthattak volna el az értelmiségi létig. Szakmai felkészültsége, társadalmi felelösségvállalása játszhatott szerepet abban, hogy 1946-ban $d r$. Csorba Zoltánt tankerületi föigazgatóvá nevezték ki, majd az iskolák államosítása, a tanügyigazgatás átszervezése után szakfelügyelői megbízást kapott.

A Lévay József nevét viselő református gimnázium 1948-ban megszűnt, Állami Földes Ferenc Gimnáziumként összeolvasztották a korábbi királyi katolikus Fráter György Gimnáziummal. Csorba Zoltán is átkerült oda. Politikai szempontok miatt háttérbe szorították ugyan, de folytathatta irodalomtörténeti publikációs tevékenységét, gyakori előadója volt a Tudományos Ismeretterjesztő Társulatnak, s szerepet kapott a miskolci irodalmi folyóiratok (a Kohó, a Borsodi Szemle, a Széphalom) megszervezésében. Egykori tanítványai elörehaladását mindvégig szemmel tartotta, magam is sokat köszönhetek ösztönzö figyelmének. Viszonylag korán, 71 éves korában, 1976. július 31-én egy budapesti kórházban hunyt el. Az 1993-ban újraindult miskolci református Lévay József Gimnázium legkiválóbb tanáregyéniségei között tartja számon őt, az iskola folyosóján a hálás tanítványok emléktáblát helyeztek el tiszteletére.

A ránk maradt életmű méltó az utókor figyelmére. Csorba Zoltán publikációi között találunk pedagógiai-módszertani írásokat (például az élőnyelvtanítás időszerü kérdéseiről 1937-ből, a tehetségmentésről 1941-ből és 1942-ből, az egyke-diákról 1944-böl, a tanulmányi versenyekröl 1955-ből); vannak az etnográfia felé mutató tematikájúak (két miskolci szólásmondást elemzett 1972-ben, s foglalkozott a miskolci temető sírfelirataival 1976-ban); írt irodalmi recenzióikat (például Ernest Hemingway Nobel-díjas kisregényéről 1956-ban, Fodor József verseiről 1963-ban, a Kazinczy-levelezés kiadásának újabb kötetéről 1960-ban); vállalt közremúködést idegenforgalmi kiadványokban (munkatársa volt a Zempléni-hegység útikalauzának 1958-ban, a miskolci útkönyvnek 1967-ben és 1973-ban). Igazi kutatási területe azonban a helyi irodalmi hagyomány volt. 1942-ben adta ki „,Miskolc és Borsod az irodalomban" címü 160 oldalas monográfiáját, amelynek bevezetésében így fogalmazta meg vállalt feladatát: „megkeresni a mi szerény, de számunkra értékes 
borsodi irodalmunknak múltba vesző szálait. A szerves egészbe: az időbe beállítani, történelemmé füzni a sok magános szigetember próbálkozásait, városunk, megyénk apró irodalmi kincseit. Meg akarom mutatni sok, az élet felületén élő miskolcinak, hogy itt nyúlnak a mélybe ősi kultúrgyökerek, és könnyen felejtö borsodiaknak szeretném megmutatni helyi irodalmunk szépségeit. Szerény müvemmel is megkedveltetni kívánnám önmagunk elött is a mi tájunkat, a mi népünket s erősíteni az azonos történelem és kultúra tudatát."1 Vagyis a maga korához kívánt szólni, a helyi történeti-irodalmi tudat kialakítására, erősítésére törekedett.

Nem „szobatudós” volt, aki filológiai apróságok felkutatásával, forráselemzéssel tölti napjait, hanem olyan tájékozott elme, aki a müvek, tények ismeretében rekonstruálni kívánja kortársai számára a régióban egykor élt írók világát. Összeállította Borsod-Abaúj-Zemplén megye irodalmi, mủvészeti és tudományos topográfiáját (1954), könyvet írt Petőfi, Tompa és Jókai borsod-miskolci kapcsolódásairól (1966), a Borsodból indult Egressy Béniről (1974), valamint a zempléni származású, Patakon diákoskodó, végül a borsodi Bánfalvára visszavonuló Kazinczy Gábor életútjáról (1970). Foglalkozott a miskolci folyóirat-kiadási kezdeményezésekkel (1954), Balassi Bálinttal (1954), Csokonai helyi kötődéseivel (1955), Kaffka Margit miskolci kapcsolataival (1955), Lenau tokaji éveivel (1955), a népszínmüíró Tóth Edével (1956), József Attila verseinek miskolci megjelenésével (1959), Szemere Bertalan szépírói tevékenységével (1967), Déryné Széppataki Róza $(1972,1974)$ és Egressy Gábor alakjával (1973), Molnár Borbála költészetével (1974), Wándza Mihály (1973) és Gvadányi József munkásságával (1975).

Elgondolkoztatta Csorba Zoltánt az a kérdés, hogy van-e a borsodi tájnak ,ízesítő, egyéniségformáló helyi színe”. Ö így látta: „,Miskolcnak nem volt olyan irodalomteremtö ereje soha, mint Nagyváradnak vagy Debrecennek. Ilyen indokom nincs is a könyv megírására. De mégis, nekünk, kik egy vármegyében közigazgatásilag, katonailag, egyházilag, kulturális élettérben, ipari és gazdasági szervezetünkben e határok közt együtt élünk, ebben a néptömbben azonos emléktartalmunk, érzelmi közösségünk és hagyománykincsünk van. Ez a közösségi összetartozás indokolja a közös irodalmi érdeklödést, és magyarázza egyes borsodi irók szellemi rokonságát, költészetük hasonló színfoltjait." ${ }^{2} \mathrm{Az}$ irodalomnak ez a szemlélete kiválthat ugyan kritikai észrevételeket, de nem tagadhatjuk jogosságát, irodalomszociológiai szempontú használhatóságát. A helyi színek, hatások, összefüggések számbavételével válik az irodalomismeret a honismeret részévé, így kerül közelebb a mai emberhez elődeinek világa, így erősödik táji kötődése. Dr. Csorba Zoltán is része immár egy tájhaza kulturális örökségének.

\footnotetext{
${ }^{1}$ Újabb kiadásban: Csorba Zoltán: Miskolc és Borsod az irodalomban. Irodalomtörténeti tanulmányok. Felsőmagyarország Kiadó, Miskolc, 1994, 9.

${ }^{2}$ Uo. 11.
} 
Mi, egykori tanítványai nemcsak a tudóst, hanem az elsősorban a nevelő embert tiszteljük benne, sokunknak adott egész életre szóló útravalót. Engem csak két évig tanított, s azok - közvetlenül a háború pusztításai után - töredékes évek voltak. Személyiségének sugárzása mégis megérintett, s igen nagy szerepe volt abban, hogy magam is a tanári pályát választottam, a pesti egyetem bölcsészkarán 1948ban magyar-angol szakra iratkoztam be. Nem is lehet pontosan nyomon követni, hogy mikor és mi által válik követendő példaképpé egy tanár valamelyik tanítványa szívében.

Azt gondolom, hogy valamilyen gyermeki vonzalom, ragaszkodás alakul ki elöbb. Mert volt valami atyai abban, ahogyan felénk fordult, mi pedig építeni próbáltunk férfias biztonságára. A nyolcosztályos gimnázium az embernevelés kiterjedt lehetőségét nyitotta meg, hiszen a tízévesen bekerülő fiúgyermek könnyen formálható, és a századok során érlelt hagyományrendszerbe belenőve tanárai szeme előtt válik éretté, felnőtté. S a tanárok munkájában többé-kevésbé megnyilatkozott az a határozott szándék, hogy a szaktárgyi ismeretanyag átadása mellett a jellem és a magatartás formálódását elősegítsék. Ezzel nemcsak a valláserkölcsi alapok megszilárdítását célozták meg, hanem egy a nemzeti közösség iránti felelősségérzettel párosuló magatartásformát állítottak célként elénk, amely cselekvő hozzáállással jár. A felnőttség tehát nemcsak bizonyos alapműveltség megszerzését jelenti ebben a felfogásban, hanem a társadalmi szerepvállalásra való készséget is. A kor, amelynek viszonyai között gimnáziumi tanulmányainkat befejeztük, segítette is, gátolta is ezt a nevelődési folyamatot. Segítette előbb a demokratikus átalakulás reményével, majd pedig korlátozta az 1948-ban bekövetkező fordulattal, amely ellenségesnek nyilvánított szinte minden nemzeti és keresztyéni gondolatot. Hamarosan magam is megtapasztaltam, hogy amire felkészítettek minket, az szembeállít az egyre diktatórikusabbá váló hatalommal. Az érettségi után négy évvel - egyetemistaként - hortobágyi számüzetésben találtam magam iskolánk egyik volt tanárával - akit 1947-ben a Kisgazdapárt képviselőjévé választottak -, valamint több száz miskolci kitelepítettel együtt.

Ezt az ellentmondásos helyzetet azért kell említenem, mert épp a nehéz időkben veszi hasznát az ember a megismert példának. Osztályunk tanulóinak életútja jól tükrözi ezt. Miközben néhányan a népi kollégiumban kapott hatások alatt egy új világ építői kívántak lenni, a fenyegető politikai légkör ellenére hatan teológián folytatták tanulmányaikat. Az iskolától kapott üzenet az volt, hogy az ember a maga adottságainak kimüvelésével keresse, és állja meg becsülettel helyét az adott viszonyok között. Hogy az elém kerülő akadályok ellenére, magam is így tehessek, ahhoz - családom mellett - nevelöimtől kaptam erőt. Közülük hatásával $d r$. Csorba Zoltán kiemelkedik.

Személyiségének egyik vonása a belső biztonságérzet kisugárzása volt számomra. Szavaiból, egész lényéből az áramlott felénk, hogy az életismeret, a szaktudás és a jellemszilárdság olyan erőforrás, amely átsegít minden nehézségen. Ta- 
lán azt is mondhatom: valamilyen szellemi fölény érződött magatartásából. Nem irántunk, nem zöldfülü tanítványaival, hanem az élet esetleges próbatételeivel szemben. Úgy éreztem, ő tudja a válaszokat nemcsak a szaktárgyaiban megjelenő problémákra, hanem minden engem foglalkoztató kérdésre. Követni akartam példáját, hogy magam is elérjem ezt a biztonságot.

Hatott rám azzal, hogy valamennyiünket ráébresztett egy önmagunkkal szembeni kötelezettségre, amit - bibliai példával élve - a ránk bízott talentumokkal való ésszerü sáfárkodásnak mondhatunk. Meglehetősen nagy létszámú fiúosztályunkban a képességek és a szorgalom tekintetében nagyon eltérö tanulók kerültek össze. De valamiben - sportban, matematikában, fogalmazásban, idegen nyelvben, rajzban mindenki lehetett kiváló. Magam is megtaláltam azokat a pontokat, amelyek által kiemelkedhettem az átlagból, s ennek köszönhetően fentebb jelzett alapismereti hiányosságaim ellenére eljuthattam a jeles érettségiig, $s$ ennek köszönhetően az egyetemi felvételig. A könyvek, az irodalom, a történelem szeretete által nyílt meg az út számomra, s e felismerésben Csorba Zoltánnak is szerepe volt. Bevitt az iskola gazdag könyvtárába, kezembe adta a klasszikusok és a népi írók könyveit, tágította érdeklődési körömet. A helyi irodalmi hagyománnyal foglalkozó könyvét is megkaptam tőle, s ezzel - nagyon burkoltan - arra emlékeztetett, hogy várnak rám is felfedezendő területek. Ez az irodalmi érdeklődés közrejátszhatott abban, hogy iskolatársaim hetedikben a Kazinczy Önképzőkör alelnökévé, nyolcadikban elnökévé választottak.

A biztonságérzet és a segítőkészség a tanári személyiség két fontos elemeként vált értékké számomra. Nagyrészt az ő hatására gondoltam azt, hogy a tanári hivatás valami különleges szerephez juttathatja az embert, hiszen utat tud mutatni másoknak. Ezzel el is dőlt a pályaválasztásom, s az ő szakjaira iratkoztam be én is pesti bölcsészkaron. De a tárgyválasztás mellett a nevelői attitüd átvétele is követendő lett a szememben. A gyerekek körében nem a fölény, hanem a felkészültségből adódó elismertség vált ki együttmüködési készséget, az a tudat, hogy a nevelö olyan értékeket közvetít, amelyek egyrészt a világ ismeretében, másrészt a személyiség fejlődésében gazdagodást hozhatnak. S ez - többek között - azt jelenti, hogy a tanítványt munkatársnak tekintjük.

Csorba Zoltán hatása később, tanár koromban is érvényesült. Azért tértem ki itt irodalomtörténeti munkásságára, mert publikációs tevékenységével a tudós tanár ideálját testesítette meg. Azét a tanárét, aki nemcsak közvetíti szaktárgyai ismeretanyagát, hanem annak gyarapításához, elemzéséhez maga is hozzájárul. Csorba Zoltán olyan tanár volt, aki feladatainak teljesítése közben időnként annak is szükségét érezte, hogy górcső alá vegye a végzett munkát, összegezze, általánosítsa az eredményeket, s ezzel mások számára is tanulsággal szolgáljon. Erre biztatott engem is, amikor már tanítottam; önképzésre, szakmai elmélyedésre, kutatásra, alkotásra serkentett. Hálás vagyok sorsomnak, hogy ilyen követendő példa megismerésére kaptam lehetőséget. 